Bedankt voor het downloaden van dit artikel. De artikelen uit de (online)tijdschriften van Uitgeverij Boom zijn auteursrechtelijk beschermd. U kunt er natuurlijk uit citeren (voorzien van een bronvermelding) maar voor reproductie in welke vorm dan ook moet toestemming aan de uitgever worden gevraagd.

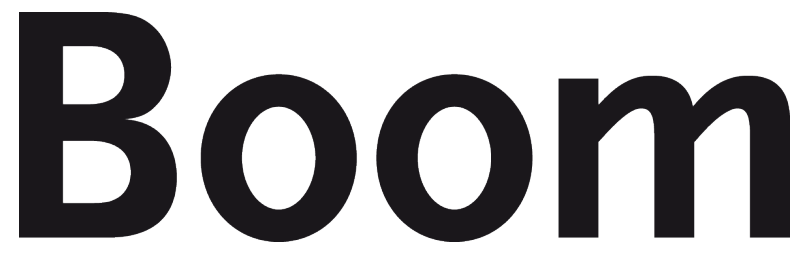

Behoudens de in of krachtens de Auteurswet van 1912 gestelde uitzonderingen mag niets uit deze uitgave worden verveelvoudigd, opgeslagen in een geautomatiseerd gegevensbestand, of openbaar gemaakt, in enige vorm of op enige wijze, hetzij elektronisch, mechanisch door fotokopieën, opnamen of enig andere manier, zonder voorafgaande schriftelijke toestemming van de uitgever.

Voor zover het maken van kopieën uit deze uitgave is toegestaan op grond van artikelen $16 \mathrm{~h} \mathrm{t} / \mathrm{m} \mathrm{16m}$ Auteurswet 1912 jo. Besluit van 27 november 2002, Stb 575, dient men de daarvoor wettelijk verschuldigde vergoeding te voldoen aan de Stichting Reprorecht te Hoofddorp (postbus 3060, 2130 KB, www.reprorecht.nl) of contact op te nemen met de uitgever voor het treffen van een rechtstreekse regeling in de zin van art. 16l, vijfde lid, Auteurswet 1912.

Voor het overnemen van gedeelte(n) uit deze uitgave in bloemlezingen, readers en andere compilatiewerken (artikel 16, Auteurswet 1912) kan men zich wenden tot de Stichting PRO (Stichting Publicatie- en Reproductierechten, postbus 3060, 2130 KB Hoofddorp, www.cedar.nl/pro).

No part of this book may be reproduced in any way whatsoever without the written permission of the publisher.

info@boomamsterdam.nl www.boomuitgeversamsterdam.nl 


\title{
REDACTIONEEL
}

\section{Arbeidsmigranten in Nederland en België}

\author{
Ive Marx \& Roel Schouteten*
}

Vlak voor de coronacrisis met ontzagwekkende kracht toesloeg, deden bedrijven in Nederland en Vlaanderen nog massaal een beroep op buitenlandse arbeidskrachten. Dat betrof dan mensen die uit de buurlanden kwamen of uit landen verder weg. De coronacrisis bracht maatregelen die ooit ondenkbaar leken, zoals het sluiten van de grenzen binnen Europa. Dat bracht veel bedrijven in nog grotere problemen. Landbouwbedrijven zagen oogsten verloren gaan bij gebrek aan arbeidskrachten. De bouwsector kwam handen te kort. Buitenlandse werknemers konden niet meer komen of wilden niet meer komen. Het bood een perfecte illustratie van hoe afhankelijk Nederland en België waren geworden van buitenlandse arbeid.

Het fenomeen arbeidsmigratie levert al wel langer de nodige controverse op. De media staan al jaren bol van berichten over fraude, sociale dumping en andere bedenkelijke praktijken. Maar tegelijkertijd geven bedrijven te kennen dat ze in toenemende mate een beroep moeten doen op buitenlandse werknemers. Ze komen niet alleen handen te kort, maar ook gespecialiseerde expertise en talent. Burgers zijn huiverachtig. Volgens de kwartaalmonitor Burgerperspectieven van het SCP maken Nederlanders zich minder druk over de economische groei dan over de sociaaleconomische gevolgen van immigratie, zoals de nijpende woningnood, die door toegenomen arbeidsmigratie alleen maar verder toeneemt. Politieke partijen roeren zich in dit debat. Zo was er de opmerkelijke samenwerking tussen de Socialistische Partij (SP) en ChristenUnie (CU), die met een plan kwamen om op Europees niveau afspraken te maken over aantallen werknemers die van het ene naar het andere land gaan. Volgens deze partijen hebben de grote aantallen arbeidsmigranten, met name uit Oost-Europa, geleid tot ernstige vormen van uitbuiting van buitenlandse werknemers. Bovendien zou ongebreidelde arbeidsmigratie het draagvlak voor de Europese Unie ondergraven.

En toch. Arbeidsmigratie is here to stay. De knelpunten op de arbeidsmarkt worden immers alsmaar structureler, al is het maar vanwege de veroudering van de bevolking. België en Nederland komen jonge mensen te kort. Maar dan stelt zich de vraag: Grijpen werkgevers niet te snel naar arbeidsmigranten? Wordt er wel voldoende werk gemaakt van de arbeidsreserve die er al is? Worden de arbeidsmigranten die naar hier komen wel goed ontvangen? Krijgen die mensen de nodige sociale bescherming? Doet men voldoende inspanningen om ze een perspectief op een beter leven te bieden? Dit themanummer werpt licht op allerlei aspecten van arbeidsmigratie in de Lage Landen.

* Ive Marx werkt bij Universiteit Antwerpen en is lid van de redactieraad van TvA (ive.marx@uantwerpen.be). Roel Schouteten werkt bij de Radboud Universiteit en is redactielid van TvA. 
Frederic De Wispelaere, Jozef Pacolet en Ludo Struyven schetsen het profiel, de omvang en de impact van tijdelijke transnationale arbeidsmobiliteit richting Nederland en België. Ze laten zien dat Nederland veelal gebruikmaakt van tijdelijke (circulaire) arbeidsmigranten die toetreden tot de Nederlandse arbeidsmarkt via het vrije verkeer van werknemers. België kent dan weer een grote instroom van gedetacheerde werknemers via het vrije verkeer van diensten. Nationale statistieken houden te weinig rekening met de in- en uitstroom van arbeidskrachten via het vrije verkeer van diensten. Daardoor ontstaat een onvolledig beeld van het aantal buitenlanders dat op een bepaald moment aan het werk is in een land. Die bevinding is van groot belang in de Europese context, in de zin dat de arbeidsmobiliteit binnen Europa wel eens veel groter zou kunnen zijn dan vaak wordt aangenomen.

Een volgende bijdrage kijkt in meer detail naar de buitenlanders die binnenkomen via het kanaal van het vrije verkeer van diensten (detachering). Dries Lens, Ninke Mussche en Ive Marx laten zien hoe belangrijk dat kanaal is. Bovendien wordt het in toenemende mate gebruikt als toegangspoort voor arbeidsmigranten uit landen van buiten de Europese Unie, als gevolg van de jurisprudentie van het Europees Hof. Dit fenomeen blijft nog onder de radar, maar heeft belangrijke gevolgen voor het Europese migratielandschap.

De CBS-bijdrage in dit themanummer, van Sophie Doove, Marion Sterk-van Beelen, Martijn Souren en Jantien van Zeijl, bespreekt de cijfers met betrekking tot een ander belangrijk segment van de vele arbeidsmigranten: de kenniswerkers die naar Nederland en België komen. Deze bijdrage laat zien dat het aandeel internationale kenniswerkers in de beroepsbevolking in Nederland relatief klein is en ook dat recente toenames vrij gering bleven in vergelijking met andere Europese landen. Maar mogelijk speelt het feit dat de gedetacheerden niet goed worden gecapteerd door de bestaande statistieken daarin een rol.

Een volgende reeks van bijdragen kijkt hoe het buitenlandse werknemers in België en Nederland vergaat. In de bijdrage 'In het web van de arbeidsuitbuiting: Ervaringen van buitenlandse werknemers in België' kijken Hanne Vandermeerschen en Lieselot Vanduynslager naar de pijnlijke realiteit van de arbeidsuitbuiting van buitenlandse werknemers. Die bestaat, vaak vlak onder onze neus. Werkgevers lijken te vaak weg te komen met uitbuiting. De auteurs documenteren dit gegeven aan de hand van een aantal diepte-interviews. Ze zien een dringende nood om de straffeloosheid van malafide werkgevers een halt toe te roepen. Dit veronderstelt onder andere voldoende (gerechtelijke) onderzoeksmiddelen.

Een vergelijkbaar beeld komt naar voren in de bijdrage van Panna Kerti en Brigitte Kroon. Hun diepgaand kwalitatief onderzoek onder Hongaarse arbeidsmigranten (free movers) in Nederlandse distributiecentra laat zien dat deze arbeidsmigranten te maken hebben met precaire werkomstandigheden, waardoor ze in stressvolle en onzekere financiële situaties terechtkomen. Op basis van de conservation of resources theory verklaren Panna Kerti en Brigitte Kroon de vicieuze cirkel van verlies van hulpbronnen, toename van stress en de onmogelijkheid tot proactief gedrag om deze cirkel te doorbreken en een betere positie op de arbeidsmarkt te verwerven.

Anita Strockmeijer belicht dan weer (vermeend) misbruik vanuit een heel andere invalshoek. In Nederland ontstond in 2018 beroering over het gebruik van Nederlandse werkloosheidsuitkeringen (WW) door Poolse arbeidsmigranten. Die 
zouden een WW-uitkering aanvragen hoewel de werkgever nog werk voor hen heeft. In de media werd gesproken over grootschalig fraude. De ophef kwam tegen de achtergrond van eerdere stemmingmakerij over uitkeringsgebruik bij migranten. Strockmeijer laat zien dat er inderdaad een grotere instroom is van Oost-Europese arbeidsmigranten in de WW. Maar het aantal dagen dat ze een uitkering ontvangen en de hoogte van de uitkering zijn aanzienlijk lager dan voor Nederlanders. Per saldo blijkt dat ze niet een onevenredig groot beroep doen op de WW.

Veel migranten vertrekken weer na enige tijd uit België of Nederland. Govert Bijwaard kijkt naar het profiel van terugkeermigranten. Keren succesvolle arbeidsmigranten, degenen met een hoog inkomen, eerder terug dan minder succesvolle migranten? Of zijn het juist de minder succesvolle migranten die ontmoedigd en teleurgesteld terugkeren? Blijkbaar is vooral het laatste mechanisme terug te vinden in de cijfers. Het zijn vooral de mensen die het niet goed doen op de Nederlandse arbeidsmarkt die terugkeren. Maar ook succesvolle arbeidsmigranten keren terug. Govert Bijwaard stipt dit aan als een beleidsuitdaging. Als men zich geen rekenschap geeft van de hoge terugkeer van deze migranten, zal dit beleid nooit leiden tot een structurele oplossing van de toekomstige schaarste op de arbeidsmarkt. Men moet dus niet alleen de instroom van hoogopgeleide migranten bevorderen, maar ook het vertrek uit ons land van zulke migranten ontmoedigen. Bijwaard stelt dat het verblijf van deze migranten vereenvoudigd moet worden. Het moet makkelijker zijn voor hun partners om te migreren. De arbeidsmigranten en hun gezinnen moeten zich thuis voelen.

Guus Bannenberg, bestuurder van Tragel, een ondersteuningsorganisatie voor mensen met een verstandelijke beperking, schetst in zijn column heel scherp dezelfde uitdaging. Aan de ene kant is er duidelijk een tekort aan arbeidskrachten, zeker ook in de zorg. Bij gebrek aan lokale kandidaten gaan organisaties als Tragel in het buitenland rekruteren. Om dan vast te stellen dat een bestuurlijk gedragen migratiebeleid uitblijft, 'wellicht uit angst voor politieke consequenties.' Er is geen geschikte huisvesting en er is geen warm verwelkomingsbeleid in scholen en andere geledingen van de samenleving. Ziedaar de uitdaging waar we voor staan.

Ten slotte schetsen Karel Neels, Julie Maes, Naomi Biegel en Jonas Wood in hun discussiebijdrage een toekomstprojectie over de noodzaak van een positief arbeidsmigratiesaldo om de Belgische beroepsbevolking op het peil van 2018 te handhaven. Arbeidsmigratie in onze contreien wordt in belangrijke mate gedreven door demografische ontwikkelingen. Die worden in de toekomst nog belangrijker. De auteurs laten de overweldigende impact van demografie zien, ook na de Great Lockdown van 2020. Er komt hoe dan ook een forse acceleratie van de vergrijzing. De babyboomgeneratie zal massaal uittreden in de periode 2020-2030. Die uitstroom wordt zelfs bij benadering niet gecompenseerd door de arbeidsmarktinstroom van de kleine cohorten geboren na 2000. De noodzaak tot een proactief en goed doordacht arbeidsmarktbeleid is daarom onverminderd. Verder is wetenschappelijk onderzoek op dit terrein, zoals de verschillende bijdragen in dit themanummer laten zien, noodzakelijk om de ontwikkeling van dergelijk beleid blijvend te informeren. 